\title{
Biological insect control using Metarhizium anisopliae: morphological, molecular, and ecological aspects
}

\author{
Controle biológico de insetos utilizando Metarhizium anisopliae: aspectos morfológicos, \\ moleculares e ecológicos
}

Patricia Vieira Tiago $^{{ }^{*}}$ Neiva Tinti de Oliveira ${ }^{\mathrm{I}}$ Elza Áurea de Luna Alves Lima

\section{ABSTRACT}

Microbial control of insects is based on the rationa use of pathogens to maintain environmentally balanced pest population levels, and Metarhizium anisopliae has been the most studied and most utilized fungal species for that purpose. The natural genetic variability of entomopathogenic fungi is considered one of the principal advantages of microbial insect control. The inter- and intraspecific variability and the genetic diversity and population structures of Metarhizium and other entomopathogenic fungi have been examined using ITS-RFLP, ISSR, and ISSP molecular markers. The persistence of $\boldsymbol{M}$. anisopliae in the soil and its possible effects on the structures of resident microbial communities must be considered when selecting isolates for biological insect control.

Key words: biological control, Metarhizium anisopliae, molecular markers.

RESUMO

O controle microbiano consiste na utilização racional de patógenos, visando à manutenção da população de insetos em equilíbrio no ambiente. Metarhizium anisopliae é a espécie mais estudada e utilizada no controle biológico de insetos. A variabilidade genética dos fungos entomopatogênicos pode ser considerada uma das principais vantagens no controle microbiano de insetos e pode ser detectada por meio de marcadores moleculares, como ITS-RFLP, ISSR e ISSP. Esses marcadores são usados para a caracterização inter e intraespecífica de Metarhizium e outros fungos entomopatogênicos e poderão auxiliar na compreensão da diversidade genética e da estrutura das populações destes fungos. A persistência de M. anisopliae no solo e seu possível efeito na estrutura da comunidade microbiana deste solo são características importantes e pouco estudadas, que devem ser consideradas no processo de seleção de isolados para o controle biológico de insetos.

Palavras-chave: controle biológico, Metarhizium anisopliae, marcadores moleculares.

\section{INTRODUCTION}

Biological control consists of the introduction of beneficial predatory or parasitic species into cultivation systems where they were previously absent or present only at low population levels. This technique is designed to negatively affect specific target species that could otherwise become pests or infectious agents (GLIESSMAN, 2001). Susceptibility to pests is a general reflection of plant health, which can be negatively influenced by poor soil fertility management (NICHOLLS \& ALTIERI, 2007). One of the objectives of biological control is to assure that the beneficial organism to be introduced can complete its lifecycle at the site, and then reproduce with sufficient efficiency to become a permanent resident of the agrosystem. Frequently, however, the niche conditions available to the beneficial introduced organism do not fully satisfy its long-term needs, requiring its reintroduction (GLIESSMAN, 2001). Changes in production practices and the use of agricultural additives are often necessary for biological control to be successful. Integrated Pest Management (IPM) is an alternative to unilateral intervention strategies using agrochemicals, with a wider focus on the ecology of the insect pests as well as the crop plants, based on the use of complementary tactics and the adoption of cultivation techniques that favor plant diversity. Pest control in this type of approach is initially based on natural agents such as pathogens,

\footnotetext{
${ }^{\mathrm{I}}$ Departamento de Micologia, Centro de Ciências Biológicas (CCB), Universidade Federal de Pernambuco (UFPE), Av. Prof. Nelson Chaves s/n, 50670-420, Recife, PE, Brasil. E-mail: patiago@hotmail.com *Autor para correspondência.
} 
parasites and predators, with the use of agrotoxins being contemplated only as a last resort. However, as biological pest control methods do not demonstrate immediate results in agro-industrial systems with large-scale production and commercialization goals (as agrotoxins), commercial groups tend to avoid the costs and labor related to their development and perfection. Nonetheless, growing energy costs, environmental degradation, and inflation all reinforce the argument that immediate financial gains should not be the principal motivating force in agricultural production (ALTIERI, 2002). In spite of the strong economic pressure on agricultural production, many farmers are making the transition to practices that are more environmentally friendly and have the potential to contribute to long-term agricultural sustainability with biological control being one of the principal tools in this conversion process (GLIESSMAN, 2001).

Microbial control is an aspect of biological insect control and consists of the rational use of pathogens to maintain pest balances in agricultural environments, with increases in the numbers of other natural enemies often being observed in fields where microbial control has been used. Successful programs of microbial control using entomopathogenic fungi to combat arthropod pests in soils and aquatic environments have been developed, principally utilizing the genera Metarhizium, Beauveria, Sporothrix, Lecanicillium, Nomuraea, Hirsutella, Aschersonia, Isaria, Paecilomyces, and Enthomophthora (ALVES \& LOPES, 2008). Species within the genus Metarhizium are pathogenic fungi having broad ranges of insect hosts. M. anisopliae was found to be a species complex composed of nine species based on multilocus phylogeny (BISCHOFF et al., 2009). The objective of this study was to analyze some morphological, molecular and ecological aspects of M. anisopliae.

\section{Metarhizium anisopliae \\ Metarhizium anisopliae, a anamorphic} fungus which belong to the phylum Ascomycota, is the most intensively studied species of the genus Metarhizium, considering that the teleomorph Cordyceps brittlebankisoides $[=$ Metacordyceps brittlebankisoides (Liu, Liang, Whalley, Yao \& Liu) Sung, Sung, Hywel-Jones \& Spatafora] was isolated from insect larva (Coleoptera: Scarabaeidae) and identified as $\boldsymbol{M}$. anisopliae var. majus [= M. majus (Johnston) Bischoff, Rehner \& Humber] (LIU et al., 2001). The reproductive structures of $\boldsymbol{M}$. anisopliae (the anamorph, the most commonly encountered form) comprise conidiophores and conidia. Leveduriform structures or blastospores and appressoria are produced by $\boldsymbol{M}$. anisopliae through mycelial differentiation. Blastospores can function in certain cases as reproductive units and are produced in submerged cultures (JACKSON \& JARONSKI, 2009) and in the hemolymph of insect hosts (ALVES, 1998). The appressoria, formed at the extremity of the hyphae, may be involved in fungus pathogenicity and have the function of initiating epicuticular and procuticle penetration of the insect tegument (ALVES, 1998). The production of microsclerotia by isolates of $\boldsymbol{M}$. anisopliae has been observed after cultivation in liquid media with different concentrations of carbon and carbon-nitrogen (JACKSON \& JARONSKI, 2009).

The fungal-host relationship occurs through the adhesion and germination of conidia on the surface of the insect, followed by hyphae penetration through the cuticle. The process of host colonization initiates after penetration, with the penetrating hyphae becoming thicker and ramify within the tegument and the hemocoel of the insect, forming blastospores. The hyphae continue to grow and invade various internal organs after the death of the host and will subsequently emerge from the insect body and produce conidia that disseminate and infect other individuals (ALVES, 1998).

Molecular studies of the processes of host infection have shown them to be complex and multifactorial. The adhesion and penetration steps have been most closely examined and appear to be decisive to infection. The participation of an adhesin coded by the gene Mad1 in the adhesion of conidia to the cuticle of Manduca sexta Linnaeus larva was demonstrated using mutants in which this gene was deleted, with these mutants demonstrating significant decreases in conidial germination, suppression of the formation of blastospores, and reduced virulence (WANG \& St. LEGER, 2007a). COSENTINOGOMES et al. (2013) described that the inhibition of phosphatase activity in the conidia of $\boldsymbol{M}$. anisopliae reduced adhesion to the integument of Dysdercus peruvianus (Hemiptera: Pyrrhocoridae) and (indirectly) its infection.

The participation of perilipin (proteins that surround lipidic droplets in the cell interior) in appressoria differentiation in $\mathbf{M}$. anisopliae has also been reported. The deactivation of the Mpl1 gene in some strains generates deficiencies in the infection process due to the formation of appressoria with lower concentrations of lipidic droplets and resultantly lower levels of osmotic pressure - resulting in difficulties in terms of hyphal penetration (WANG 
\& St. LEGER, 2007b). Defective appressoria were also observed after the deletion of the mapka1 gene (catalytic subunit 1 of the protein kinase A) (FANG et al., 2009). Subtilisin-type proteases have been intensively studied in penetration processes, and 10 genes are known to code for different isoforms of these enzymes (Pr1A - Pr1J) and appear to reflect specificity in relation to different hosts (BAGGA et al., 2004). MOS1 is another protein with an apparent role in the adaptation of fungi to the high osmotic pressure encountered in insect hemolymph (WANG et al., 2008). Other genes, such as Mcl1 (collagenlike protein), Cag8 (which regulates the $G$ protein signaling pathway), chi2 (endochitinase), chi3 (endoand exochitinase), and Mpk1 (phosphoketolase) are known to be involved in the host infection processes of $M$. anisopliae, with reductions in virulence if they are inactivated (FANG et al., 2007; BOLDO et al., 2009; DUAN et al., 2009). SU et al. (2013) undertook comparative proteomic analyses of the conidia and mycelia of M. anisopliae (Ma1291). The proteins identified as exclusive to the conidia were involved in protective processes, appressorium formation, and the degradation of the host cuticle and exclusive proteins to mycelia were involved in biosynthetic and energy-generating metabolic processes, such as UTPglucose-1-phosphate uridylyltransferase and heatshock protein 70 .

\section{Molecular characterization}

Molecular markers can represent the phenotype of an expressed gene or a DNA segment corresponding to a non-expressed region of the genome. Advances in molecular biology have resulted in the development of various methods for detecting genetic polymorphism at the DNA level and have aided our understanding of genetic diversity and the population structures of fungi populations (FALEIRO, 2007).

The polymerase chain reaction (PCR) technique, allied to methodologies of cloning and DNA sequencing, have allowed the rapid accumulation of information relating to genome structure and the discovery of repetitive DNA sequences (which are rich sources of genetic polymorphism). A number of methodologies have been described for analyzing polymorphisms based on PCR, including ITS-RFLP (Internal Transcribed Spacer - Restriction Fragment Length Polymorphism), ISSP (Intron Splice Site Primer), ISSR (Inter Simple Sequence Repeats), and SSR (Simple Sequence repeats) (FALEIRO, 2007).

The DNAs coding for rRNA are arranged as genetic aggregates with three genetically conserved regions composed of $18 \mathrm{~S}, 5.8 \mathrm{~S}$ and $28 \mathrm{~S}$ genes that are transcribed and processed to generate mature rRNA, but are separated by variable intergenic spacer regions denominated ITS1 and ITS2. The genetic aggregate that codes for rRNA appears to be repeated hundreds of times in the fungus genome and demonstrates both highly conserved and variable regions, allowing scientists to analyze variations at different taxonomic levels. The $18 \mathrm{~S}$ region is the most highly conserved, and is therefore only used in comparisons between distantly related organisms. The $28 \mathrm{~S}$ region is more variable and therefore appropriate for comparing different genera (or different species, in some cases). ITS regions evolve relatively rapidly and can be used to distinguish closely related species or even varieties within the same species (FUNGARO, 2000).

DNA samples digested with restriction enzymes (RFLP) can identify polymorphisms based on the numbers and sizes of the fragments produced, which allows the differentiation of species and isolates of Metarhizium based on the presence or absence of rDNA restriction sites (PIPE et al., 1995). In the present study, isolates of $\boldsymbol{M}$. anisopliae could be grouped according to their geographical origins, although no significant correlations were observed in terms of their hosts. VELÁSQUEZ et al. (2007) observed that there were no associations between the diversity of isolates of $\boldsymbol{M}$. anisopliae from different regions in Chile and their geographic origins. ITSRFLP was used to define specific primers that could be used to detect and identify $\boldsymbol{M}$. anisopliae var. anisopliae (DESTÉFANO et al., 2004).

Eukaryotic chromosomes contain genes that are separated by non-coding regions (introns) as well as regions with coding information represented by proteins (exons). Introns can be separated into four basic categories according to their structural characteristics and self-splicing mechanisms: group I, II, nuclear pre-mRNA, and nuclear tRNA. The introns of groups I and II are classified according to their internal organizations and have the intrinsic capacity of self-splicing; the latter two intron groups can be used as molecular markers in intra- and interspecific studies of diversity (HAUGEN et al., 2005).

Group I introns are encountered in eukaryotic organisms such as fungi, protists, and green algae in nuclear, mitochondrial, and chloroplast genomes. Group I introns are encountered in the eukaryotic nuclear genome in rDNA genes at specific sites that code for the larger and smaller rRNA subunits. These introns are autonomous genetic elements characterized by their capacity to transfer from one allele to another (as some are mobile 
elements - transposons) and by their ability to selfsplice from RNA transcripts (HAUGEN et al., 2005). Group I introns are generally irregularly distributed - being present in some isolates but absent in others - and thus can serve as markers of genetic variability. Genetic diversity among M. anisopliae isolates have been observed in studies of genes associated with the largest ribosomal subunit and with four insertion sites of group I introns, and the presence/absence of these introns allow the delimitation of seven groups (MÁRQUEZ et al., 2006).

Microsatellite DNAs show numerous short, repeated, tandem sequences, and their analyses involve replicating fragments containing those repetitions through the use of oligonucleotides that bind to the regions which flank them (SSR sites). These markers were used to examine polymorphism in $\boldsymbol{M}$. anisopliae, but the primers used to examine samples derived from soil cores from different regions in Chile (VELÁSQUEZ et al., 2007) and numerous countries in Asia and Europe (FREED et al., 2010) were not efficient in detecting informative polymorphisms. To the contrary of microsatellite analysis, the ISSR technique amplifies fragments located between two repetitive regions present in various genomes (FALEIRO 2007), known as inter-microsatellite regions. This ISSR marker did demonstrate differences among different isolates of M. anisopliae var. anisopliae of the same origin and from the same host, principally when using the primers $(\mathrm{GACA})_{4}$ and $(\mathrm{GTG})_{5}$, providing DNA fingerprints for a number of isolates (TIAGO et al., 2011). The genetic structure of Metarhizium spp. (M. anisopliae and its sister species, M. robertsii), pathogens found in Chinese burrower bugs populations (Schiodtella formosana), were assessed using ISSR. They differentiated into two main clades including over $71 \%$ of all strains causing epizootics, with a similarity of $83 \%$ (LUAN et al., 2013).

The soil ecology of Metarhizium anisopliae Metarhizium anisopliae demonstrates considerable metabolic and ecological versatility and has been observed colonizing the rhizosphere and adhering to the surfaces of plant roots, and it may significantly influence this ecological niche by repelling and killing soil insects (HU \& St. LEGER, 2002). BRUCK (2005) observed that the conidia of M. anisopliae demonstrated greater persistence in the rhizosphere of Picea abies Linnaeus than in the soil alone. On the other hand, a pilot study by St. LEGER (2008) in a pasture site indicated that $\boldsymbol{M}$. anisopliae could survive for various years in the soil, although with fluctuations in its population levels. Additional studies will therefore be necessary to determine if the plant rhizosphere can truly be considered a refuge (a locality where the fungus can survive outside its insect host) for $M$. anisopliae in the soil. MEYLING \& EILENBERG (2007) suggested that plant associations are important to the biological cycle of M. anisopliae in temperate regions. It is possible that this fungus has multiple functions in terms of plant protection, with antagonistic effects against phytopathogenic fungi.

A number of studies have examined the molecular mechanisms involved in the capacity of M. anisopliae to adhere to both insects and roots, resulting in the identification of adhesins MAD1 and MAD2. Adhesin MAD1 is involved in insect pathogenicity and MAD2 with fungal adhesion to plant roots (WANG \& St. LEGER, 2007a), and a study by WANG et al. (2005) examining genetic expression demonstrated that $\boldsymbol{M}$. anisopliae could act as both a pathogen (growing on the cuticle and in the hemolymph of insect hosts) and a saprophyte in the rhizosphere (growing on the bean root exudates). WYREBEK \& BIDOCHKA (2013) amplified and cloned the full Mad1 and Mad2 genes in fourteen isolates of seven different species of Metarhizium to assess their genetic variability. Phylogenetic analyses of $5^{\prime} \mathrm{EF}-1 \alpha$ (which is used for species identification), Mad1, and Mad2 indicated that the evolution of the Mad2 gene was more congruent with the phylogeny of 5' EF-1 $\alpha$ than of Mad1. This suggests that Mad2 diverged among the Metarhizium lineages and contributed to clade- and species-specific variations, while Mad1 was largely conserved.

Studies have shown that some insect pathogenic endophytic fungi, such as Metarhizium, are able to transfer insect-derived nitrogen to plant roots, probably in exchange for plant sugars. Metarhizium has a phylogenetic heritage of plant symbiosis (i.e., the genus is closely related to other endophytes) and has also evolved as a generalist insect pathogen (BEHIE et al 2013).

A number of workers have investigated the persistence of $\boldsymbol{M}$. anisopliae in the soil, with greater fungal survival being observed in sandy-clay soils and in soils with average compaction density values (LANZA et al., 2004). High average numbers of colonies of M. anisopliae could be recovered 30 days after inoculation, and viability for up to 120 days was observed in previously sterilized soils (GUERRA et al., 2009) and for up to 216 days after field inoculation (MARTINS et al., 2004). A study based on quantitative PCR (qPCR) demonstrated that 
Metarhizium Clade 1 (M. majus, M. guizhouense, M. pinghaense, M. anisopliae, M. robertsii, M. brunneum) was present at high densities in soil samples from pastures and improved field margins, indicating that both of these semi-natural habitat types provide potential refuges for these species (SCHNEIDER et al., 2012).

The introduction of exogenous microorganisms into natural and agricultural ecosystems may affect the soil microbial community and, consequently, diverse ecological processes in those environments. The effects of the introduction of entomopathogenic fungi into soil microbial communities represent an ecological intervention that has not yet been extensively examined. A study by SCHWARZENBACH et al. (2009) using ribosomal internal spacer analysis (RISA) to examine the effects of $\boldsymbol{B}$. brongniartii on fungal community structures in soil microcosms indicated that its presence in the soil without the presence of its insect host had only small (or transitory) effects on the soil fungal community; this result differed from the situation after using the insecticide Carbofuran, which demonstrated significant impacts even at the end of the experimental period. Other studies using the DGGE technique indicated that the fungal soil community structure was not significantly influenced by the presence of $\boldsymbol{M}$. anisopliae var. anisopliae URM5951 at 15, 30, 60, and 90 days after its inoculation in the soil (TIAGO et al., 2012).

\section{CONCLUSION}

Molecular genetic techniques can be useful in addressing taxonomic problems and in determining degrees of inter- and intraspecific genetic variation. Polymorphism studies have contributed to our understanding of the genetic diversity and population structures of fungi and have provided information that can be very important to programs of biological control. Molecular biological techniques have important roles in our understanding of the genes involved in host infection processes, such as the adhesion steps, appressorium formation, and the degradation of the host cuticle. Measures of the persistence of entomopathogenic fungi in the soil and any possible effects of their application on the structural and functional diversity of soil or rhizosphere microbial communities are essential ecological aspects that must be understood in agrosystems, as these microorganisms represent a significant fraction of the soil biota in terms of its species diversity and the multiplicity of metabolic activities occurring in that milieu. Metarhizium is a plant symbiont that can act as a saprophyte in the rhizosphere but has also evolved as a generalist insect pathogen. As such, the paradigm that M. anisopliae is principally an insect pathogen is questionable, and additional studies will be necessary to better understand its ecological role in the soil.

\section{REFERENCES}

ALTIERI, M. Agroecologia: bases científicas para uma agricultura sustentável. Guaíba: Agropecuária, 2002. 400p.

ALVES, S.B. Controle microbiano de insetos. Piracicaba: FEALQ, 1998. 1163p.

ALVES, S.B.; Lopes, R.B. Controle microbiano de pragas na América Latina: avanços e desafios. Piracicaba: FEALQ, 2008. $414 \mathrm{p}$.

BAGGA, S. et al. Reconstructing the diversification of subtilisins in the pathogenic fungus Metarhizium anisopliae. Gene, v.324, p.159-169, 2004. Available from: <http://www.sciencedirect.com/ science/article/pii/S0378111903009582>. Accessed: Dec. 19, 2012. doi: 10.1016/j.gene.2003.09.031.

BEHIE, S.W. et al. Nutrient transfer to plants by phylogenetically diverse fungi suggests convergent evolutionary strategies in rhizospheric symbionts. Communicative \& Integrative Biology, v.6, p.e22321, 2013. Available from: <http://www. landesbioscience.com/journals/cib/2012CIB0104.pdf>. Accessed: Dec. 19, 2012. doi: 10.4161/cib.22321.

BISCHOFF, J.F. et al. A multilocus phylogeny of the Metarhizium anisopliae lineage. Mycologia, v.101, p.512-530, 2009. Available from: $<$ http://www.mycologia.org/content/101/4/512.full.pdf $>$. Accessed: Dec. 19, 2012. doi: 10.3852/07-202.

BOLDO, J.T. et al. Endochitinase CHI2 of the biocontrol fungus Metarhizium anisopliae affects its virulence toward the cotton stainer bug Dysdercus peruvianus. Current Genetics, v.55, p.551-560, 2009. Available from: <http://link.springer.com/ content/pdf/10.1007\%2Fs00294-009-0267-5>. Accessed: Dec. 19, 2012. doi: 10.1007/s00294-009-0267-5.

BRUCK, D.J. Ecology of Metarhizium anisopliae in soilless potting media and the rhizosphere: implications for pest management. Biological Control, v.32, p.155-163, 2005. Available from: $<$ http://naldc.nal.usda.gov/download/1708/PDF $>$. Accessed: Dec. 19, 2012. doi: 10.1016/j.biocontrol.2004.09.003.

COSENTINO-GOMES, D. et al. Inhibition of ecto-phosphatase activity in conidia reduces adhesion and virulence of Metarhizium anisopliae on the host insect Dysdercus peruvianus. Current Microbiology, v.66, p.467-474, 2013. Available from $<$ http://link. springer.com/content/pdf/10.1007\%2Fs00284-012-0296-z.pdf\#>. Accessed: Dec. 19, 2012. doi: 10.1007/s00284-012-0296-Z.

DESTÉFANO, R.H.R. et al. Detection of Metarhizium anisopliae var. anisopliae within infected sugarcane borer Diatraea saccharalis (Lepidoptera, Pyralidae) using specific primers. Genetics and Molecular Biology, v.27, p.245-252, 2004. Available from: <http://www.scielo.br/pdf/gmb/v27n2/a20v27n2. pdf $>$. Accessed: Dec. 19, 2012. 
DUAN, Z. et al. A phosphoketolase Mpk1 of bacterial origin is adaptively required for full virulence in the insect-pathogenic fungus Metarhizium anisopliae. Environmental Microbiology, v.11, p.2351-2360, 2009. Available from: <http://onlinelibrary. wiley.com/doi/10.1111/j.1462-2920.2009.01961.x/pdf $>$. Accessed: Dec. 19, 2012.

FALEIRO, F.G. Marcadores genético-moleculares aplicados a programas de conservação e uso de recursos genéticos. Planaltina: Embrapa Cerrados, 2007. 102p.

FANG, W. et al. Protein kinase A regulates production of virulence determinants by the entomopathogenic fungus, Metarhizium anisopliae. Fungal Genetics and Biology, v.46, p.277-285, 2009. Available from: $<$ http://www.lfsc-courses.umd.edu/cv/docs/ entm_cv/mpavarip/05_Wang_Pava-Ripoll_Etal_2009_PKA.pdf $>$. Accessed: Dec. 19, 2012. doi: 10.1016/j.fgb.2008.12.001.

FANG, W. et al. A regulator of a $\mathrm{G}$ protein signalling (RGS) gene, cag8, from the insect-pathogenic fungus Metarhizium anisopliae is involved in conidiation, virulence and hydrophobin synthesis. Microbiology, v.153, p.1017-1025, 2007. Available from: <http:// mic.sgmjournals.org/content/153/4/1017.full.pdf $>$. Accessed: Dec. 19, 2012. doi: 10.1099/mic.0.2006/002105-0.

FREED, S. et al. Determination of genetic variability among the isolates of Metarhizium anisopliae var. anisopliae from different geographical origins. World Journal of Microbiology and Biotechnology, v.27, p.359-370, 2010. Available from: <http:// link.springer.com/content/pdf/10.1007\%2Fs11274-010-0466-8>. Accessed: Dec. 19, 2012. doi: 10.1007/s11274-010-0466-8.

FUNGARO, M.H.P. PCR na micologia. Biotecnologia Ciência \& Desenvolvimento, v.14, p.12-16, 2000. Available from: $<\mathrm{http}: / /$ www.biotecnologia.com.br/revista/bio14/pcrnamicologia.pdf $>$. Accessed: Dec.19, 2012.

GLIESSMAN, S.R. Agroecologia: processos ecológicos em agricultura sustentável. Porto Alegre: UFRGS, 2001. 653p.

GUERRA, D.M.S. et al. Persistência de Metarhizium anisopliae spp no solo sob diferentes condições de temperatura e umidade. Revista Caatinga, v.22, p.18-22, 2009. Available from: <http:// periodicos.ufersa.edu.br/revistas/index.php/sistema/article/ view/266/624>. Accessed: Dec. 19, 2012.

HAUGEN, P. et al. The natural history of group I introns. Trends in Genetics, v.21, p.111-119, 2005. Available from: <http://www. bch.umontreal.ca/cours/BCM-2002/Publications/Introns-groupIHaugen2005.pdf $>$. Accessed: Dec. 19, 2012. doi: 10.1016/j. tig.2004.12.007.

HU, G.; St. LEGER, R.J. Field studies of a recombinant mycoinsecticide (Metarhizium anisopliae) reveal that it is rhizosphere competent. Applied Environmental Microbiology, v.68, p.6383-6387, 2002. Available from: <http:/www.ncbi.nlm. nih.gov/pmc/articles/PMC134390/>. Accessed: Dec. 19, 2012. doi: 10.1128/AEM.68.12.6383-6387.2002.

JACKSON, M.A.; JARONSKI, S.T. Production of microsclerotia of the fungal entomopathogen Metarhizium anisopliae and their potential for use as a biocontrol agent for soil-inhabiting insects. Mycological Research, v.113, p.842-850, 2009. Available from: $<$ http://naldc.nal.usda.gov/download/33311/PDF>. Accessed: Dec. 19, 2012. doi::10.1016/j.mycres.2009.03.004.
LANZA, L.M. et al. População de Metarhizium anisopliae em diferentes tipos e graus de compactação do solo. Ciência Rural, v.34, p.1757-1762, 2004. Available from: <http://www.scielo.br/ pdf/cr/v34n6/a14v34n6.pdf>. Accessed: Dec. 19, 2012.

LIU, Z.Y. et al. Cordyceps brittlebankisoides, a new pathogen of grubs and its anamorph, Metarhizium anisopliae var. majus. Journal of Invertebrate Pathology, v.78, p.178-182, 2001. Available from: $<$ http://cordyceps.us/files/Liu et al 2001 brittlebankisoides.pdf>. Accessed: Dec. 19, 2012. $\overline{\text { doi: }} \overline{10} .100 \overline{6} /$ jipa.2001.5039.

LUAN, F. et al. Genetic diversity of the fungal pathogen Metarhizium spp., causing epizootics in chinese burrower bugs in the Jingting Mountains, eastern China. Molecular Biology Reports, v.40, p.515-523, 2013. Available from: $<$ http:// link.springer.com/article/10.1007\%2Fs11033-012-2088-8\#>. Accessed: Dec. 19, 2012. doi: 10.1007/s11033-012-2088-8.

MÁRQUEZ, M. et al. Detection of potentially valuable polymorphisms in four group I intron insertion sites at the 3'-end of the LSU rDNA genes in biocontrol isolates of Metarhizium anisopliae. BMC Microbiology, v.6, p.1-8, 2006. Available from: <http://www.ncbi.nlm.nih.gov/pmc/articles/PMC1578565/ pdf/1471-2180-6-77.pdf $>$. Accessed: Dec. 19, 2012. doi: 10.1186/1471-2180-6-77.

MARTINS, J.F.S. et al. Eficiência de Metarhizium anisopliae no controle do percevejo-do-colmo Tibraca limbativentris (Heteroptera: Pentatomidae) em lavoura de arroz irrigado. Ciência Rural, v.34, p.1681-1688, 2004. Available from: <http://www. scielo.br/pdf/cr/v34n6/a03v34n6.pdf>. Accessed: Dec. 19, 2012.

MEYLING, N.V.; EILENBERG, J. Ecology of the entomopathogenic fungi Beauveria bassiana and Metarhizium anisopliae in temperate agroecosystems: potential for conservation biological control. Biological Control, v.43, p.145-155, 2007. Available from: <http://www1.bio.ku.dk/forskning/oe/cse/media/ meylingandeilenberg.2007.biocontrol.pdf>. Accessed: Dec. 19, 2012. doi: 10.1016/j.biocontrol.2007.07.007.

NICHOLLS, C.I.; ALTIERI, M.A. Projeção e implantação de uma estratégia de manejo de habitats para melhorar o controle biológico de pragas em Agroecossistemas. In: NICHOLLS, C.I. et al. Controle biológico de pragas através do manejo de agroecossistemas. Brasília, MDA, 2007. Cap.1, p.2-16.

PIPE, N.D. et al. Restriction fragment length polymorphisms in the ribosomal RNA gene complex of isolates of the entomopathogenic fungus Metarhizium anisopliae. Mycological Research, v.99, p.485-491, 1995. Available from: <http://www.sciencedirect.com/ science/article/pii/S0953756209806515>. Accessed: Dec. 19, 2012. doi: 10.1016/S0953-7562(09)80651-5.

SCHNEIDER, S. et al. Spatial distribution of Metarhizium clade 1 in agricultural landscapes with arable land and different seminatural habitats. Applied Soil Ecology, v.52, p.20-28, 2012. Available from: $<$ http://www.sciencedirect.com/science/article/pii/ S0929139311002265>. Accessed: Dec. 19, 2012. doi: 10.1016/j. apsoil.2011.10.007.

SCHWARZENBACH, K. et al. Effects of biological and chemical insect control agent on fungal community structures in soil microcosms. Applied Soil Ecology, v.42, p.54-62, 2009. Available from: $<$ http://www.sciencedirect.com/science/article/pii/ S0929139309000298>. Accessed: Dec. 19, 2012. doi: 10.1016/j. apsoil.2009.02.001. 
St. LEGER, R.J. Studies in adaptations of Metarhizium anisopliae to life in the soil. Journal of Invertebrate Pathology, v.98, p.271-276, 2008. Available from: <http://www.sciencedirect.com/ science/article/pii/S0022201108000608>. Accessed: Dec. 19, 2012. doi: 10.1016/j.jip.2008.01.007.

SU, Y. et al. Proteins differentially expressed in conidia and mycelium of the entomopathogenic fungus Metarhizium anisopliae sensu stricto. Canadian Journal of Microbiology, v.59, p.443448, 2013. Available from <http://www.nrcresearchpress.com/ doi/abs/10.1139/cjm-2013-0096>. Accessed: Dec. 19, 2012. doi: 10.1139/cjm-2013-0096.

TIAGO, P.V. et al. Persistence and effect of Metarhizium anisopliae in the fungal community of sugarcane soil. BioControl, v.57, p.19, 2012. Available from: <http://link.springer.com/content/pdf/1 0.1007\%2Fs10526-012-9445-3>. Accessed: Dec. 19, 2012. doi: $10.1007 / \mathrm{s} 10526-012-9445-3$.

TIAGO, P.V. et al. Intraspecific polymorphism in Metarhizium anisopliae var. anisopliae (Hypocreales: Clavicipitaceae) based on molecular markers ITS-RFLP, ISSR and Intron. Genetics and Molecular Research, v.10, p.1565-1575, 2011. Available from: $<$ http:/geneticsmr.com//year2011/vol10-3/pdf/gmr1069.pdf $>$. Accessed: Dec. 19, 2012. doi: 10.4238/vol10-3gmr1069.

VELÁSQUEZ, V.B. et al. Intraspecific differentiation of chilean isolates of the entomopathogenic fungi Metarhizium anisopliae var. anisopliae as revealed by RAPD, SSR and ITS markers. Genetics and Molecular Biology, v.30, p.89-99, 2007. Available from: <http://www.scielo.br/pdf/gmb/v30n1/17.pdf $>$. Accessed: Dec. 19,2012 . doi: $10.1590 /$ S1415-47572007000100017.

WANG, C. et al. MOS1 osmosensor of Metarhizium anisopliae is required for adaptation to insect host hemolymph. Eukaryotic
Cell, v.7, p.302-309, 2008. Available from: <http://www.ncbi.nlm. nih.gov/pmc/articles/PMC2238159/pdf/0310-07.pdf>. Accessed: Dec. 19, 2012. doi: 10.1128/EC.00310-07.

WANG, C.; St. LEGER, R.J. The MAD1 adhesin of Metarhizium anisopliae links adhesion with blastospore production and virulence to insects, and the MAD2 adhesin enables attachment to plants. Eukaryotic Cell, v.6, p.808-816, 2007a. Available from: <http://www.ncbi.nlm.nih.gov/pmc/articles/PMC1899246/ pdf/0409-06.pdf $>$. Accessed: Dec. 19, 2012. doi: 10.1128/ EC.00409-06.

WANG, C.; St. LEGER, R.J. The Metarhizium anisopliae perilipin homolog MPL1 regulates lipid metabolism, appressorial turgor pressure and virulence. Journal of Biological Chemistry, v.282, p.21110-21115, 2007b. Available from: <http://www.jbc. org/content/282/29/21110.full.pdf + html>. Accessed: Dec. 19, 2012. doi: 10.1074/jbc.M609592200.

WANG, C. et al. Differential gene expression by Metarhizium anisopliae growing in root exudate and host (Manduca sexta) cuticle or hemolymph reveals mechanisms of physiological adaptation. Fungal Genetics and Biology, v.42, p.704-718, 2005. Available from: <http://www.stlegerlab.umd.edu/pub/WangFGB2005-42.pdf>. Accessed: Dec. 19, 2012. doi: 10.1016/j. fgb.2005.04.006.

WYREBEK, M.; BIDOCHKA, M.J. Variability in the insect and plant adhesins, Mad1 and Mad2, within the fungal genus Metarhizium suggest plant adaptation as an evolutionary force. PLoS ONE, v.8, p.e59357, 2013. Available from: $<$ http://www. plosone.org/article/fetchObject.action?uri=info\%3Adoi\%2F10.13 71\%2Fjournal.pone.0059357\&representation=PDF $>$. Accessed: Dec. 19, 2012. doi:10.1371/journal.pone.0059357. 